\title{
Adopting a Janus perspective: moving forwards and backwards through our teacher professional experiences
}

The paper reports on collaborative journal writing and dialogue sustained by two education professionals with a view to engaging in meaningful reflective practice. The transition from journal writing to reporting in this paper was underpinned by knowledge of the place of reflective practice in teacher education and continuous professional development. Knowledge of the limited opportunities and time for meaningful continuous professional development; as experienced across the education sector, also informed a desire to share the writing experience with a view to encouraging other teachers to develop writing communities.

As teacher educators, we relate how we came to write together and sustained a dialogue that provided us with newly framed insights in to our professional lives and experiences. Our journalling told our stories and was very much in the spirit of evocative autoethnography. We describe how we naturally included sensory description related to the time and place of writing. We also used more evocative language, including the use of metaphors. Themes of critical reflection, reflexivity, embodied reflection and evocative autoethnography are therefore explored in the light of our writing experience. The journals and the associated dialogue highlight the values of such small and time constrained moments as informal professional development opportunities.

Keywords: reflective and reflexive practices; autoethnography; teacher education; professional development 


\section{Introduction}

In the paper, we share our reflections on the process of collaborative writing (and its later data analysis) in relation to our evolution as teacher educators. The choice to write this paper as 'we' rather than 'the authors' or 'the researchers' is deliberately in the spirit of the autobiographical writing we present. We are both experienced teacher educators, now working at a university as Senior Lecturers in Post Compulsory Education. We have both worked in post compulsory i.e. further education college contexts, and our teaching continues to centre on Post Compulsory teaching practices and context.

In a series of reflective journals (the data set for this paper), we recognise that we are expressing, inhabiting and interpreting the experiences we 'story' (Bolton 2014; Mattingly 1991). In those journals, we found ourselves looking both forwards and backwards through our professional experiences. In Kinsella's (2007, p.396) terms, we were engaging in 'an embodied mode of reflection, in that it arises through the bodily, lived experience of the practitioner and is revealed in action'. This connects to writing on autoethnography i.e. Spry (2016, p.113): 'whatever we say or do it is within a material body that we do it. It is inside a material body that we live.'

\section{Informal learning}

As will be explained more fully in the next section, the reflective journals were written initially as part of a collaborative informal writing group with other education colleagues. The aim was simple: to talk about and to write about ourselves as teachers and teacher educators. Coia and Taylor (2009, p.4), writing as co/autoethnographers and in the role of teacher educators, reflect: 'We tell stories about ourselves and others in order to understand what we are doing or what we have just done'. We were writing with a view to sharing and exploring/ re-exploring/ learning from our experiences. The 
richness of the group dialogues is not captured in this paper but we would echo Coia and Taylor's (2009, p.4) sense that: 'There is no such thing as a discussion of the disembodied or impersonal practice of teaching'; the personal and professional are interwoven. There were other less explicit aims such as: to write because we are university lecturers and writing (research) is an expectation, to write reflexively because reflexive practices are central to teacher education, and to explore and potentially model a way of writing about professional experiences that could inform future research projects and could foster writing communities for fellow teachers.

We both share an aspiration to develop collaborative writing as a process through which to support other teachers to share and learn from their experiences. Writing projects such as the one we propose have been written about elsewhere i.e. Turner, Hughes and Brown (2009), Turner et al (2014). It is not therefore an original perspective but such work is not currently visible to us as teacher educators working with a range of institutions in the post compulsory sector. Where such collaboration exists, it tends to sit in the assessment requirements for reflective practice (journals) on teacher education courses; such as the Postgraduate Certificate for Post-Compulsory Education (PGCE PCE) on which we both teach and post teacher education qualifications i.e. M.A. in Education/ Professional Practice.

\section{Our research approach}

From June 2016 to June 2017, we were both members of a small informal collaborative writing group made up of colleagues and led by Author. In meetings with the writing group, we generated key themes or questions to which we wanted to respond. The journals responded to the following: 'Why do I stay in teaching?'; 'Facilitating learning or It's not about teaching, it's about learning'; 'Being a teacher who is also teacher educator'; 'Teacher as Researcher'. Each member variously contributed reflections that 
were shared with the rest of the group. Later, we (Author and Co Author) became a writing duo. At the heart of our collaboration is a desire to present an informal, manageable (as fluid and as established and negotiated between peers) and meaningful way of reflecting on your practice as informal continuous professional development. Our writing experience has been supported by our discussions and has provided a sustained process of reflection and development. In the spirit of autoethnography and reflective practices, we have examined the present while also travelling forwards and backwards through our experiences.

The process of sharing, discussing, writing saw us return to our journals to add a reflection on 'Who am I as teacher today' (July/ August 2017). We wanted to continue to represent some of the emotional context of being a teacher who is also a teacher educator, as well as sustain our shared writing. Once we had collated our journals, we each took on the role of researcher, analysing the other's data set and then sharing our interpretations. The process relied on a strong and trusting personal/professional relationship as honest and open dialogue (verbal and written) were at the heart of the collaboration. Echoing Brookfield (1995, p.26) on critical reflection, in our sharing and analysis, we were 'mak(ing) public disclosure of private realities' in order to see and experience it through each other's eyes.

\section{Teacher perceptions and experiences of continuous professional development}

Many teachers hunger for what they would describe as meaningful CPD and their appetite often goes un-fed. Borg (writing for the British Council 2015, p.3) states that ' $\mathrm{CPD}$ is often equated with talks, workshops and courses that teachers attend. While such activities have a role to play in teacher development, much work has been carried out internationally in recent years to extend established views of what CPD involves'. He cites reviews: '(for example, Broad and Evans 2006; Orr et al. 2013; Timperley et 
al. 2008) through which key characteristics of effective CPD have been identified'. In synthesising those review recommendations, Borg suggests that: 'They share a concern for participatory, social, inquiry-driven and evidence-based professional learning which is set in context, and where teachers are the key decision-makers (although....appropriate expert support and leadership are also key contributors to effective CPD)'. That 'concern' (ibid) is in synergy with this paper which seeks to place emphasis on the values of informal professional learning opportunities.

CPD available to practitioners across the field of education is often limited to the dissemination of internal policy and procedures and in-house processes or faddish flavours of the month. In a paper arguing for more effective CPD for school teachers, Kempton (2013, p.14-15) describes how:

The classic image of teacher CPD is likely to involve a teacher going out of school for a one day course with professionals from other schools. While off site courses can be effective for filling gaps in knowledge, there are many more effective interventions for changing teaching habits, such as a focus on research informed ideas, observation, joint practice development and collaborative learning, coaching, and social media based learning.

Morrison-McGill (2013), also reflecting on school teacher CPD experiences, writes: I dream of a day where CPD is so inherently established that it becomes part of every teacher's bloodstream; that accumulating a feathered-cap of personal development becomes the norm, not a desire for the determined and those with funds liberally allocated for Inset courses, master's degrees and those with time on their hands.

There appears to be a general lack of meaningful and affordable pedagogical CPD opportunities; affordable in terms of both finance and time. As opportunities for 
accessing professional development within and external to organisations diminish, SET (Society for Education and Training) offers opportunities for post compulsory teachers and trainers to belong to a virtual community of professional practice. Such a community can offer support, guidance and most importantly relevant CPD.

\section{Continuous professional development in post compulsory education}

In focusing on post compulsory education, we refer to the SET and to sector professional standards. Those standards underpin teacher education qualifications and inform continuous professional development expectations for practitioners.

The Society for Education and Training (SET) is the professional membership organisation of the Education and Training Foundation (ETF) which is the professional body for post-compulsory practitioners. Teachers and trainers are not required to be members of SET but many choose to become a member and sign up to a Code of Practice (SET 2017a) which, 'sets out the professional behaviour and conduct expected of members of SET, including mandatory requirements which must be complied with to become and remain a member'. In 2014, in collaboration with post-compulsory practitioners, ETF (SET 2017b) created 'a set of aspirational Professional Standards' intended to provide a framework for teachers and trainers to critically appraise their own practice and improve their teaching. Included in the 20 Education and Training Foundation professional standards (2014) are the standards:

7. Maintain and update knowledge of your subject and/or vocational area

8. Maintain and update your knowledge of educational research to develop evidence-based practice (p.3).

Standards also refer to the need to reflect and make adjustments to your practice ongoing i.e. 
1. Reflect on what works best in your teaching and learning to meet the diverse needs of learners.

2. Evaluate and challenge your practice, values and beliefs (p.2).

These particular statements have been included in order to briefly indicate a few of the continuous professional development expectations which are captured in the Professional Standards.

In 2012; as then Chief Executive for the Institute for Learning (succeeded by the Education and Training Foundation), Toni Fazealli reflected that 'our [IfL] surveys on the effectiveness of CPD [continuous professional development] in colleges and providers over the past three years show how much effective CPD can be delivered through collaborative professional learning activities, created and led by teachers themselves and backed by IfL (or a similar college of teaching)'. However, in June 2017, the Further Education Workforce Data for England (ETF) recorded: 'a majority of teachers (over 60\%) report spending no time at all on CPD [Continuous Professional Development]' (p.31). In a Times Educational Supplement (Belgutay, June 2017) article reporting on those findings, the University College Union (UCU) general secretary Sally Hunt was quoted saying: 'Busy staff already have massive workloads, so colleges need to make time and resources available so all staff have the opportunity to access CPD'.

Professionalism is central to the mission of the Society for Education and Training (SET 2017c) who identify their goal as: 'to help teachers and trainers develop and improve their skills to enhance their own professional standing, and with it the wider quality and recognition of the education and training system'. SET members commit to undertaking continuing professional development (CPD) that has an impact on practice and demonstrates improvement in relevant knowledge and skills in the 
teacher's subject area and their pedagogical practice (thus working within the Professional Standards already identified). Members can access 'Foundation learning on-line' which hosts a series of webinars and on-line courses. Further opportunities for development are offered via the Qualified Teaching, Learning and Skills (QTLS) status described as 'the badge of professionalism for post-16 education and training, helping practitioners advance in their careers and demonstrate their expertise and experience to colleagues, employers and learners' (SET 2017d). There is now the Advanced Teacher Status (ATS) which is 'aimed at teachers and trainers who want to develop and demonstrate mastery in their practice and their increasing role in supporting others, mentoring and working collaboratively with peers, sharing effective practice, and improving the quality of teaching within their organisation or network' (Society for Education and Training 2017e) and is designed to offer another route to become a fellow of SET which, up until now, was only available to those who hold a masters level qualification.

\section{Teacher development through and post teacher education}

Teacher education programmes in the post compulsory education sector are underpinned by the Professional Standards (ETF 2014) already described. Teacher education encourages student teachers to envision and then enact and develop a professional teacher 'identity'. The intrinsic element of most teacher education programmes is the development and sustaining of a close knit group who, through group discussion and reflection on significant learning episodes in their teaching practice, build a learning community. This shared discourse and membership of a community (Lave and Wenger 1991) builds trust and honesty between new teachers and is often seen as an important learning opportunity and source of much needed support (see Wright, Loughlin and Hall 2017). 
Once qualified, there are comparatively fewer opportunities for a teacher to sustain that ongoing supportive focus on their development. As noted in a paper on transitions in notions of identity as expressed by beginning teachers (Wright, Loughlin and Hall accepted for publication 2018), teachers may well miss the community of practice (Lave and Wenger 1991) that was part of their teacher education.

As teachers progress through their career, the need for practice centred professional development arguably increases as; from our experience, the career of a teacher in PCE (and in the education sector as a whole) is punctuated by regular change. Changes in curriculum, whether by topic, level or legislation are a regular occurrence and teachers have to continue to develop and refine strategies to work with students with a wide range of needs and preferences. Essential CPD opportunities are therefore often best characterised as swift and fleeting i.e. a conversation across the desks in the staff office which spring up and dissipate as the need flows and ebbs. These are conversations in passing: in effect, they are 'corridor learning' exchanges in which teachers grab five minutes of each other's time between timetable commitments. The acceptance of such 'corridor learning' opportunities is further compounded by many organisations' promotion of hot-desking and the removal of staff rooms. The fluidity of the teacher's role, which is often one of constant activity and movement, with little time in a full time teaching timetable to share with colleagues, thus provides little or no opportunity for peer learning, support or time to seek or give advice. Hence, the new way to engage colleague support seems to be 'on-the-move'. This corridor learning has benefits but what opportunities are being lost? There is little room for the natural growth of ideas, experience and shared creativity. There are few opportunities to engage in meaningful action research that directly impacts on learners and the teacher's practice and ultimately the organisation. Post- teacher education, what opportunities are there for 
teachers to maximise such informal learning opportunities, alongside more formal continuous professional development? In the financially and time depleted PCE environment, an informal writing group experience such as the one we reflect on in this paper might provide the opportunity for a naturally evolving and sustained continuous professional development experience.

\section{Reflective and reflexive practices}

"The insistence that the oppressed engage in reflection on their concrete situation is not a call to armchair revolution. On the contrary, reflection - true reflection - leads to action' (Freire 2000, p.66).

Professional Standard numbers 1 and 2 (ETF 2014) emphasize the place of reflection in a practitioner's development. As in all teacher education programmes, in our roles as teachers on the PGCE in Post Compulsory Education, we support our students in becoming critically reflective practitioners. We ask that they engage with the process of self and peer reflection in order to gain sight of how to advance and improve their practice. Foucault (1988 in Martin and Hutton), in later writing on the 'technologies of self', explores an early Greek concept called 'care of self' whereby an individual continually exercises 'vigilance'. Such vigilance underpins ongoing critical reflection. Akin therefore to Foucault's perspective on 'care of self' as ongoing moral/ ethically informed self-examination, the practice of critical reflection ensures that we (as a community of practitioners) are not 'trapped in unexamined judgements, interpretations, assumptions and expectations' (Larrivee 2000, p.293). If we do not develop our 'selfefficacy' (ibid, p.294) to explore and design personal solutions to issues, we leave ourselves floundering in a sea of undiscovered answers. To critically reflect is to take control and responsibility for what happens in our classrooms and to avoid Freire's 
(1993) idea of 'magical consciousness'; i.e. that the classroom is beyond our control and 'subject to whimsical blessings and curses' (Larrivee 2000, p.297).

From the perspective of students on a teacher education programme, reflection often leads to specific action points. Such an action point might be an informed (and typically negotiated between themselves and their tutor or mentor) adjustment to evidence in their next lesson observation. As new teachers, it is appropriate that they are facilitated to explore and take up opportunities for adjustment (working to develop and extend their teaching and learning approaches). In her application and interpretation of the place of visual metaphor within reflective practice, Hunt (2006) argues against a more prescriptive A to B form of reflection (reflection explicitly for the purpose of triggering an action). She emphasizes some of the more instinctual, potentially emotional, creative/ imagined, and embodied characteristics of reflective practices to which we have alluded earlier (i.e. Kinsella 2007).

From our own perspectives as teachers and teacher educators, reflection is a process through which we might feel more empowered, one that might support increased insight in to our emotions and values, and that might stimulate action in which we regain control and a sense of perspective as to where we are now. In writing collaboratively, we actively created space and time in which to stop and examine the ways we work and how we make sense of the choices we make. Wheatley (2006, p.147) identifies the importance of reflection being ever greater as we become busier: 'in spite of our hurry, we cannot stop life's dynamic of self-reference or the human need for meaning'. Through our journals, we explored how and in what ways we were shaping our sense of ourselves as teachers and teacher educators; how 'the algebra of absolutes explodes in a kaleidoscope of shapes that jar' (Plath; poem 'Love is a Parallax'). The questions we agreed to write about were deliberately thought-provoking for us, pushing 
us to reflect on our careers, asking us to justify our everyday practices, challenging us to look for our own truths.

\section{Storying/ story-telling/ evocative autoethnography}

The method we chose for our reflective writing was a storytelling model (Mattingly 1991). It fitted well with our collegial style of sharing classroom experiences informally. The casual sharing of our day can be a useful starting point to reflect on what has gone well and what hasn't. For those of us lucky enough to have a colleague with a sympathetic ear and a few wise words, we can usually un-pick difficulties and begin to see a way forward. We intended to be our own 'sympathetic ear' and to challenge ourselves to explain our thoughts and actions with our own 'wise words'. For Co Author, the storytelling method appealed in a way that other, more formal models did not.

Co Author: 'I liked the idea of 'constructing a narrative' (Kuit and Reay 2001) and exploring what that narrative means to me. The exploratory nature of seeing what I would write and beginning to construct meaning through my own interpretation drew me to the method. The next issue was to decide where and how to start. I found that where I wrote was important. I found I couldn't reflect effectively without planning my surroundings carefully. I knew I needed time and space but I was surprised that the environment was also important. I found writing outside or by a window encouraged me to start. I could describe what I could see, what I could hear and smell and then it was an easier step to write what I thought. Boud and Walker (1993) explore barriers to reflection and suggest that 'hostile or impoverished environments' can affect our ability to think in ways that lead to meaningful reflection. My writing space during the summer was a garden seat, quiet and peaceful.' 
Author: 'I have written elsewhere about autoethnography as a way of writing in which I become more visible as researcher/ teacher/ writer. We are all autoethnographers when we write (graphy) autobiographical stories (auto) that directly relate to and will inevitably reference the socio-cultural and historical context in which we are placed as teachers (ethno). For me, writing about my practice is a way of seeing it more clearly, situating it for a moment outside of my self: quite literally placing it with my pen on the page or typing it in to Word. Like Co Author, I often include where I am when I reflect (in one journal, I referred to the fact I was sitting in a green armchair). That recognition of where I am places me in that moment, as transient but no less important for that.'

In our reflections, as will be apparent in the data analysis and as is indicated in our dialogues above, we 'talk through' our thoughts: where we are; the sensory element of reflection is captured as an essential part of our reflective process. The use of evocative language and explicit use of metaphor is woven through our writing to create images and feelings. Hunt (2006, p.315) discusses how the use of metaphor provides a link "between the private and often idiosyncratic world of 'felt reality' and the propositional world of theories and constructs". Our writing is naturally aligned to evocative autoethnography. Carolyn Ellis and Art Bochner (2016) coined the term 'evocative autoethnography' through which to describe a research approach lying between social sciences and the humanities, and in which the researchers' own lived experiences are shared. Autoethnography is a label that covers lots of different approaches, some of which are explicitly performative/ enacted. Bochner and Ellis (2016, p.186) characterise evocative autoethnography as privileging the story: 'the story itself should always occupy a prominent position'. Ellis (Bochner and Ellis, ibid, p.188) suggests that: 'You find autoethnography because of your interest in storytelling and 
lived experience'. For ourselves, in starting to write autobiographically, we needed a clear sense of purpose. We felt this was important to enable us to see how, by engaging in shared reflective writing (story telling/ evocative autoethnography), we could benefit as practising teachers who have years of teaching experience.

\section{Analysing the data}

The data analysis occurred in phases and was supported (launched and reviewed) in discussion with each other. As already noted, we each took on the researcher role analysing each other's journal set and therefore variously inhabited positions of researcher/ researched, insider/ outsider, subject/ object.

- Phase One:

In September 2017, we had five journals and we each started to read through and think about what themes/ ideas were emerging in each other's data set. This resonates with grounded theory (Glaser and Strauss 1967). We created mind-maps which we then shared and discussed with each other.

- Phase Two:

Through discussion and the sharing of mind maps, we moved to refine our themes and to analyse the data using constant comparative analysis (comparing across all journals) (Silverman 2005). The process of synthesising the initial themes in to four main themes saw us work to justify and explain to each other why and how those themes were connected. One decision saw us identify both 'teacher' and 'teacher educator' roles (theme 1). Another decision was to subsume all notes on imaginative/ creative/ evocative language, and use of metaphors as 'evocative writing' (theme 4). The final themes were agreed as:

(1) Ongoing development of teacher and teacher educator self-identity

(2) Norms and expectations 
(3) Wellbeing

(4) Evocative writing

- Phase Three:

We analysed each other's data sets by noting the theme, identifying examples, and writing memos in a table template (Glaser 1965). The memos allowed a space for each of us to reflect in our own ways on our interpretations of the data. Sometimes memos also recorded questions for discussion. We were not seeking to re-story the experiences but to explore how and where the data talked to the main themes we had identified.

- Phase Four:

We compared and checked our interpretations in a follow up meeting in October. We also asked any questions we had in relation to our personal interpretations of each other's data (i.e. 'is this the sense you were communicating?').

\section{Data presentation}

- Theme 1: Ongoing development of teacher and teacher educator self-identity

This theme was important to us as it connected explicitly to our own autobiographies in making transitions from being a teacher (a subject teacher) to being a teacher who became (is also) a teacher educator. To clarify, as teacher educators, our 'teacher' should role model appropriate and effective teaching and learning practices. Sometimes when we are teaching, we explicitly ask our student teachers to tell us why we have done a particular thing (asking them to critique the approach both with a view to supporting our 'reflection in action' (Schön 1991) in effect 'freeze-framing' it and also opening ourselves/ our practices up so as to explicitly illustrate being a reflective practitioner (see ETF 2014 Professional Standards 1 and 2), as well as signposting an approach they might try. While we would not say that we are always personally secure 
and confident in all of our approaches; as can be seen in our journals, we are also subject to 'imposter syndrome' (Brookfield 1995), we prioritise being open, explicitly sharing and critiquing in order to learn from our students and from each other.

In Co Author's journals, she described the teacher/ teacher educator as 'a multitalented multi- tasker' who might not have any answers. The managerial/ directive dimension to the role is also examined: 'Once the students arrive it takes a leap of faith to pass responsibility for learning over to the students'. In doing so, the teacher is required to make a 'judgement' in which their 'role is to teach them to get to this point'. In the same journal, she identifies the facilitator as the more 'challenging' role, acknowledging the requirements for time, space, and creative thinking in planning stage.

In Author's journal, she notices how her perspective of teaching has changed over time and with experience. Reflecting on herself as a younger teacher she notes: 'I have occasionally observed people (teachers) I felt had become tired, tired, tired' and strongly asserts how she never wanted to become like them. Today, with the benefit of professional maturity she observes that this critical perspective was possibly naïve though she 'still holds to some of that same critical perspective'.

In another journal, Co Author reflects: 'perhaps what teacher educators should be focusing on is helping students develop their resilience, their confidence, their critical argument so they can be bottom-up change agents'. A questioning glance is directed to the notion of 'effective teacher' i.e. 'what are these mysterious attributes?' and to the role of the teacher educator in identifying and developing such teachers. She emphasizes the recognition and enactment of a 'value-centred approach' in which; supported by teacher educators, 'new teachers would be consciously embedding their values into their teaching'. 


\section{- Theme 2: Norms and expectations}

This theme captured some of the explicit, publicly known, parameters in which a teacher functions, for example: the government policies, the influence of stakeholders such as Ofsted, the institutions' own quality mechanisms and processes, and how the language employed becomes a 'truth game' (Foucault 2003 in Rabinow and Rose 2003) that serves to regulate how those processes are perceived and enacted. In one of Co Author's journals, she explained: 'A teacher working in FE knows there are two constants in their work, limited time and constant change' and they work to respond to 'the latest version of whatever constitutes 'outstanding'. The theme also led to examples of more subjective and personalised interpretation such as: the more recent use of the word 'resilient' for both students and teachers; the sense that we ourselves have particular core values and practices that we wish to embody; the fact that sometimes these tacit needs/ values that we have are tacit as they are only allowed to 'exist' when we, as teachers, shut the classroom door and teach our students. We both came in to teaching thinking we were going to teach. Author's words describe this 'real work' of teachers as 'ever complex and unfathomable'. The longer we have spent in 'teaching', the more we have been 'collating data about retention, attendance and punctuality' (Co Author) and, at various points, questioned the use of, interpretation and purpose of that data. The perspective/ identification of the top down managerialism of Further Education is reported and critiqued elsewhere (see Smith and O’Leary 2013).

For Co Author, such reflections saw her re-emphasize: 'Organisational demands cannot be allowed to suffocate the real work of teachers'. In Author's exploration of the language used to describe what we do as teachers, she reflected on the term 'facilitating', asking 'am I instead 'regulating' learning rather than facilitating it?' She 
describes 'regulating' as in part protecting her students. She is: 'regulating (their) perspectives that I know they need to have in the context in which they teach.'

\section{- Theme 3: Wellbeing}

This links to the previous theme and the word 'resilience'. Through this theme, we sought to identify that 'resilience of spirit' (Co Author) that we feel is required as teacher. A resilience that includes that persistence and self-efficacy that we have to foster and that we have to ensure our student teachers start to foster. It interacts very much with the challenges and tensions that are variously expressed in the theme of norms and expectations. Within our role as teacher educators, we reflect ongoing on how we support our students to develop that strong emotional and moral wellbeing. For Author, personally managing stress meant at times thinking about 'one day as a small unit'. She captured the concept of the teacher as the 'all seeing eye, the all hearing ear', someone who can 'pick up quickly on conversations students have' and then skilfully weave them into the narrative of learning. Co Author wrote how: 'A teacher in the FE sector can easily be recognised by the speed they move (between classrooms, students, meetings) and often, the anxious or harassed expression that can be seen on their face.' We both thought similarly about the determined professional who will keep on making adjustments to improve the experience of the students and their own practice in the face of lots of different and variously 'excessive demands' (Co Author).

\section{- $\quad$ Theme 4: Evocative writing}

As already alluded to, our collaborative writing process became a place for exploration that led both of us to write in a more informal and at times creative way in order to express our thoughts and feelings. The 'space' for writing was also our physical space i.e. our surroundings, sometimes what we were sitting on and what we were wearing, and such descriptions provided a holistic sensory representation. We both sought to 
maintain control of the 'present' writing moment by communicating when and how and where it took place and in order to explore the 'why/s' e.g. 'gaze out of window whilst trying to string a sentence that reflects what I think' (Co Author), (Author): 'at my desk, and typing -in work mode and seemingly 'official' though in jeans and a summery top...', 'We are sitting at a round table in the refectory...I am starting to scribble'. In our writing, there were lots of instances of metaphorical and evocative language. Metaphors became a lens through which to capture the actual/ real role (as perceived by us) and practices of the teacher and the teacher educator. In table 1 [Table 1 near here], we share some of the images we employed.

\section{Reflecting back on the collaborative writing process}

As illustrated in Table 1, we found we had both employed more creative/ dramatic language at times so as to draw the other person in to the experience. This is very much in tune with evocative autoethnography where your representation (writing) 'is about a connection. You have to accept and treat the reader as a co-constructor of the meaning of your text' (Bochner: Bochner and Ellis 2016, p.247). It also resonates with Mattingly's (1991, p.248) clarification that: Narratives... nearly always contain an evocative element that draws listeners into an empathic identification with the protagonist.' Reiterating an earlier point, we saw that such writing choices had helped us personally to envision/ explain our thoughts and feelings.

Looking forwards and backwards through your writing with someone else does require a strong degree of trust. In collaborating on this paper, we have variously exerted and balanced our own editorial perspectives. The stream of consciousness journalling expressed an open and honest sharing of our 'real' thoughts in an unabridged sense. In evocative autoethnography, Bochner (Bochner and Ellis 2016, p.248) reminds us: 'You keep in mind your allegiance to real events and experiences as 
you understand them, but your focus shifts to the work of making a story of them'. He explains: 'I want to be faithful to the past, but what I remember of experiences I lived through is anchored by what summons me now to remember' (p.251). For Co Author, that re-remembering was initially fraught with emotional tension/ resistance.

Co Author: 'I found reflection hard. I found it uncomfortable. I didn’t particularly want to force an analysis of self, actions and thoughts for fear of what I might discover. Boud and Walker (1993) discuss obstructive feelings restricting the reflective process. The suggestion of lack of confidence and fear of failure resonated strongly with me and made it very difficult to start.

My 'way in' to sharing my thoughts and finding a voice was helped greatly by the use of four approaches: situated writing, where I was, my 'safe space for writing', and sensory description; what I could see and hear, a written picture of where I was. The third approach was the use of evocative language to encourage the reader into my space and help them to see through my lens. The fourth was the use of metaphor which I found the most useful way of trying to explain what I thought and felt in way that made it clearer to the reader but also helped me to explore some complex thoughts, emotions and ideas.

I found reflective writing to be both an emotive and strenuous project. Where to start? How to start? The writing of thoughts and events alone is not enough! The questioning and engaging in continual re-scripting are needed for successful reflection (Usher 1997) and it is this analysis of thoughts and actions that forces us to face our self 'head on' and ask some difficult questions. Questions we may rather leave alone, quietly hidden under our piles of marking telling ourselves we haven't the time to explore them today. Engaging in critical reflection takes courage. Exploring and questioning our beliefs can be disarming. We are made up of our beliefs, they are part 
of ourselves 'hence shedding a dearly held belief shakes our very existence' (Larrivee 2000, p.295).’

Author: 'In thinking again about the process of reflective writing, I am drawn to some of Co Author's word choices in her entry above: 'uncomfortable', 'emotive', 'strenuous', 'disarming'. Writing as stream of consciousness/ storying inevitably involves representing and then sharing a vulnerable self. I mentioned earlier in this paper that I wrote an autoethnographic thesis for my doctorate. There were a few goals at the heart of that decision, not least to critically examine my practice (as tutor observer). It is exposing to write in such a way. It provokes difficult and uncomfortable sifting through and framing of experiences. For me, it was morally important and it became the only way through which I felt I could begin to 'see' my practice more clearly. You cannot escape the exploration of your attitude, values and approaches if you choose to situate yourself back in the past and re-examine experience through a new 'present' lens.'

\section{Conclusion}

In reflecting back on the writing process (both the journals and the construction of this paper), we re-state Turner et al's (2015, p.552) note that: 'Writing represents only a snapshot in time that does not define the person who produced the writing'. In an exploration of what it means to write evocative autoethnography, Ellis (Ellis and Bochner 2016, p.225-226) reflects:

I want readers to consider how partial, tentative, and incomplete our stories and memories can be; how through our lives we constantly revise, reframe, and reinterpret our lives, yet feel a desire to view our lives as a continuous and coherent whole. 
Writing as stream of consciousness reflected our shared perspective that lots of aspects of our work/ our roles remain in flux and we (our personal-professional selves) are ever evolving. The increasing ease with which we were able to write in such a way (freely, stream of consciousness) also reminded us that we do actually have confidence in what we do (the professional values we adhere to). We are both experienced in our work and have had various positions of responsibility. To an extent therefore, the journaling reflected our realisation that we do have something to say that is important. The writing is a mirror that we have held up to ourselves. In storying our reflections, we have shared some of what we know, some of what we think we know, and some of how we feel about what we know. It is in sharing that writing with a trusted colleague that we have added depth and dimension to our reflections. We have seen our experiences from another's perspective, finding symmetry in shared perceptions, and movement in our own and each other's expressions of selves.

\section{Recommendations}

We hope to have highlighted how valuable such a collaborative writing process might be, not just because it is informal and can be negotiated between participants, but also because it affords opportunities to share and learn from each other's perspectives. This paper has been written in recognition of those two constants in every teacher's lives (across the education sector): 'limited time and constant change' (Co Author). It has also been written with direct insight; through our teaching experiences, in to the emphasis on ongoing reflective practices in teacher education and continuous professional development. In the Introduction, we used the word 'evolution' to begin to describe a continuous process of experiencing, re-experiencing/ re-remembering/ reshaping our personal-professional lives as teachers and teacher educators. Time 
constrained writing moments and conversations, if sustained by us, can still supply an important opportunity to stop, reflect, evaluate, and re- assemble.

\section{References}

Belgutay, J. 2017. Most teachers have no CPD, report shows. Times Educational Supplement. Available from: https://www.tes.com/news/further-education/breakingnews/most-fe-teachers-have-no-cpd-report-shows [Accessed 30 November 2017]. Brookfield, S.1995. Becoming a critically reflective teacher. San Francisco: Jossey Bass Bochner, A. and Ellis, C. 2016. Evocative Autoethnography: Writing lives and telling stories. New York: Routledge Bolton, G. 2014. Reflective Practice: Writing and Professional Development. 4th ed. London: SAGE Publications.

Borg, S. 2015. Teaching for Success: Contemporary perspectives on continuing professional development. British Council. Available from: https://www.britishcouncil.in/sites/default/files/contemporary_perspectives_on_cpd.pdf [Accessed 16 December 2017].

Boud, D. and Walker, D. 1993. Barriers to Reflection on Experience. In: Boud, D. et al. (eds.) Using experience for learning. Buckingham, SRHE and Open University Press. Coia, L., \& Taylor, M. 2009. Co/autoethnography: Exploring our teaching selves collaboratively. In: Tidwell, D., Heston, M.L. and Fitzgerald, L.M. (eds.), Research methods for self study practice. Dordrecht, The Netherlands: Springer Press, 3-16. Education and Training Foundation (ETF) (2014) Achieving Professional Potential: Professional Standards for Teachers and Trainers in Education and Training. ETF accessed 31/10/17 http://www.et-foundation.co.uk/wpcontent/uploads/2014/05/ETF_Professional_Standards_Digital_FINAL.pdf 
Education and Training Foundation (ETF) 2017 Further Education Workforce Data for England: Analysis of the 2015-2016 Staff Individualised Record (SIR) data. Available from: http://www.et-foundation.co.uk/wp-content/uploads/2017/06/FE-workforce-data2017-FINAL.pdf [Accessed 31 October 2017].

Fazaeli, T. 2012 Achieving excellence in teaching and learning. FE Week. Available from: https://feweek.co.uk/2012/05/11/achieving-excellence-in-teaching-and-learning/ [Accessed 21 November 2017].

Foucault, M. 1988. The Political Technology of Individuals. In: Martin, L. and Hutton, P. (eds.) Technologies of the Self: A Seminar with Michel Foucault. London: Tavistock Publications Ltd, 145-163.

Foucault, M. 2003. Technologies of the Self. In: Rabinow, P. and Rose, N. (eds.) The Essential Foucault: Selections from the Essential Works of Foucault, 1954-1984. New York: The New Press, 145-170.

Freire, P., 2000. Pedagogy of the Oppressed. New York: Continuum.

Hunt, C. 2006. Travels with a turtle: metaphors and the making of a professional identity. Reflective Practice, 7 (3), 315-332.

Kempton, J. 2013. To teach, to learn: More effective continuous professional development for teachers. CentreForum. Available from: http://www.centreforum.org/assets/pubs/teacher-cpd-web.pdf [Accessed 16 December 2017].

Kinsella, E.A. 2007. Embodied Reflection and the Epistemology of Reflective Practice. Journal of Philosophy of Education, 41 (3), 395-409.

Kuit, J and Reay, G.2001. Experiences of Reflective Teaching. Active Learning in Higher Education, 2 (2), 128-142, London: Sage. 
Larrivee, B. 2000. Transforming Teaching Practice: becoming a critically reflective teacher. Reflective Practice, 1 (3), 293-307.

Lave, J. and Wenger, E. 1991. Situated learning: Legitimate peripheral participation. Cambridge: Cambridge University Press.

Mattingly, C. 1991. Narrative Reflections on Practical Actions :Two learning experiments in reflective storytelling. In: Schon, D.A. (eds.) The Reflective Turn: Case studies in and on reflective practice. San Francisco: Jossey-Bass.

Morrison-McGill, R. 2013. Professional Development for teachers: how can we take it to the next level? The Guardian. Available from: https://www.theguardian.com/teachernetwork/teacher-blog/2013/jan/29/professional-development-teacher-training-needs [Accessed 30 November 2017].

Plath, S. Love is a Parallax. Available from: https://www.poetrysoup.com/famous/poem/love_is_a_parallax_15219 [Accessed 19 December 2017]

Schön, D. 1991. The Reflective Practitioner: How professionals think in action. Aldershot: Arena.

Silverman, D. 2005. Doing qualitative research. London: SAGE.

Smith, R. and O’Leary, M. 2013. New Public Management in an age of austerity: knowledge and experience in further education. Journal of Educational Administration and History, 45 (3), 244-266.

Society for Education and Training. 2017a. Code of Professional Practice. Available from: https://set.et-foundation.co.uk/membership/code-of-professional-practice/ [Accessed 30 November 2017]. 
Society for Education and Training. 2017b. Professional Standards. Available from: https://set.et-foundation.co.uk/professionalism/professional-standards/[Accessed 30 November 2017].

Society for Education and Training. 2017c. Professionalism. Available from: https://set.et-foundation.co.uk/professionalism/ [Accessed 30 November 2017]. Society for Education and Training. 2017d. Professional Formation. Available from: https://set.et-foundation.co.uk/professionalism/qtls/professional-formation/[Accessed 30 November 2017].

Society for Education and Training. 2017e. What is ATS. Available from: https://set.etfoundation.co.uk/professionalism/ats/what-is-ats/ [Accessed 30 November 2017]. Spry, T. 2016. Autoethnography and the Other: Unsettling Power through Utopian Performatives. Oxon: Routledge.

Turner, R., Hughes, J. and Brown, T. 2009. (eds.) Putting the I into Identity and other Stories: scholarly approaches to the professional identity and development of H.E. practitioners in FE colleges. Joint HELP CETL/ESCalate Publication. Available from http://escalate.ac.uk/downloads/6105.pdf [Accessed 28 November 2017].

Turner, R., Brown, T., Edward-Jones, A., Hughes, J. et al. 2014. Narrative explorations into the professional development of lecturers teaching higher education in English further education colleges. Professional Development in Education, 41:3, 546-562. University and College Union (UCU). 2017. Helping you in your career. Available from: http://cpd.web.ucu.org.uk/2013/06/17/ucu-helping-you-in-your-career/ [Accessed 31 October 2017].

Usher, R. et al. 1997. The Reflective Practitioner Revisited in Adult Education and Postgraduate Challenge. London: Routledge. 
Wheatley, M.J. 2006. Leadership and the New Science. San Francisco: Berrett-Koehler Publishers Inc.

Wright, V., Loughlin, T., Hall, V. 2017. Lesson observation and feedback in relation to the developing identity of student teachers. TEAN Journal, 9 (1), 100-112.

Wright, V., Loughlin, T., Hall, V. accepted for publication 2018. Exploring transitions in notions of identity as perceived by beginning post-compulsory teachers. Research in Post Compulsory Education 
Table 1. Evocative writing examples

\begin{tabular}{|c|c|}
\hline Language & Our explanation \\
\hline holding the reins & $\begin{array}{l}\text { Asking therefore whether I am in control } \\
\text { of the classroom- in a guiding way, being } \\
\text { in charge, leading. }\end{array}$ \\
\hline teacher as amplifier & $\begin{array}{l}\text { Sharing one student's idea with the rest of } \\
\text { the class }\end{array}$ \\
\hline Curator, convenor, medium & $\begin{array}{l}\text { gatherer of thoughts... every student's } \\
\text { voice needs to be heard }\end{array}$ \\
\hline Hopping about on hot sand & do I know enough? \\
\hline $\begin{array}{l}\text { 'I just keep swimming’ (echoing Dorey, in } \\
\text { the film Finding Nemo) }\end{array}$ & $\begin{array}{l}\text { referring to the surprise destination of } \\
\text { teaching in HE (as teacher educator) }\end{array}$ \\
\hline one day as a small unit & $\begin{array}{l}\text { a coping strategy for mental and } \\
\text { emotional resilience? }\end{array}$ \\
\hline The teacher as one who knows all things! & Deliberately ironic! \\
\hline the answer is 42 (Hitchhikers guide) & $\begin{array}{l}\text { Again deliberately ironic and reflecting on } \\
\text { the authority of the teacher (as expert) }\end{array}$ \\
\hline Wrestling with self & $\begin{array}{l}\text { Dilemma / conflict between personal } \\
\text { values and professional role }\end{array}$ \\
\hline $\begin{array}{l}\text { Seeing colleagues sprinting along the } \\
\text { corridors, I was part of that ineffective } \\
\text { race through the day, the term, the year. }\end{array}$ & $\begin{array}{l}\text { Exploring some of the tensions and } \\
\text { parameters we work within }\end{array}$ \\
\hline So there can be bottom-up change-agents & In contrast to top down management of \\
\hline
\end{tabular}




\begin{tabular}{|c|c|}
\hline $\begin{array}{l}\text { working from within to create pockets of } \\
\text { optimism within the institutions }\end{array}$ & teachers \\
\hline $\begin{array}{l}\text { The teacher as 'ringmaster' maître'd, film } \\
\text { director. }\end{array}$ & $\begin{array}{l}\text { The classroom as performative, } \\
\text { interactive learning climate }\end{array}$ \\
\hline If good teaching was a cake & $\begin{array}{l}\text { Good teaching is context bound and } \\
\text { complex }\end{array}$ \\
\hline $\begin{array}{l}\text { the sharing of the secret; magic space; } \\
\text { invisible circle }\end{array}$ & $\begin{array}{l}\text { Complexity of teaching and learning: it } \\
\text { cannot be reduced to a checklist. }\end{array}$ \\
\hline $\begin{array}{l}\text { the teacher is front and centre and in that } \\
\text { space their words become all powerful }\end{array}$ & $\begin{array}{l}\text { Explicit visible power dynamic in the } \\
\text { classroom }\end{array}$ \\
\hline $\begin{array}{l}\text { my professional standing balancing } \\
\text { precariously on their achievements }\end{array}$ & $\begin{array}{l}\text { Our students' achievements and progress } \\
\text { are seen to directly reflect on our work } \\
\text { with them as teachers }\end{array}$ \\
\hline Teacher educator as a carpenter & whittling away and carving new teachers \\
\hline Nurturing / a mother hen & $\begin{array}{l}\text { An important personal and professional } \\
\text { reward: seeing them (students/ student } \\
\text { teachers) grow }\end{array}$ \\
\hline $\begin{array}{l}\text { I'm a gatherer of thought, a collector of } \\
\text { ideas }\end{array}$ & $\begin{array}{l}\text { Describing the work of the teacher in the } \\
\text { teacher educator classroom }\end{array}$ \\
\hline
\end{tabular}

